\title{
PESANTREN CIPASUNG DI BAWAH KEPEMIMPINAN K.H. RUHIAT (STUDI KETERLIBATAN KIAI DALAM PERJUANGAN KEMERDEKAAN)
}

\author{
PESANTREN CIPASUNG IN THE CONDUCTION OF K.H. RUHIAT'S \\ (STUDY OF KIAI'S INVOLVEMENT IN STRUGGLE FOR INDEPENDENCE)
}

\author{
Adeng \\ Balai Pelestarian Nilai Budaya Bandung \\ Jl. Cinambo 136 Ujungberung Bandung. \\ e-mail: adeng.tedja@ymail.com
}

\begin{abstract}
Abstrak
Pondok pesantren merupakan lembaga pendidikan dan pengajaran agama Islam secara tradisional yang tumbuh dan berkembang di tengah-tengah masyarakat. Seiring dengan perkembangan zaman, pondok pesantren tradisional berubah menjadi pondok pesantren modern dengan tidak meninggalkan agama sebagai pijakan. Perkembangan ini sudah mulai tampak sejak awal abad ke-20, dengan berdirinya pesantren-pesantren modern dan atau berubahnya pesantren tradisional menjadi pesantren modern. Pesantren tersebut mengalami pergeseran orientasi, dengan tidak hanya mengajarkan masalah uhkrowi (keagamaan/akhirat) semata tetapi juga masalah keduniawian. Hal ini tercermin dari penyesuaian-penyesuaian yang telah pesantren lakukan dalam menghadapi zaman yang semakin maju, salah satu pesantren tradisional yang berkembang menjadi pesantren modern adalah Pesantren Cipasung Singaparna, Kabupaten Tasikmalaya. Penelitian ini diharapkan dapat mengungkap sejarah perkembangan Pesantren Cipasung Singaparna. Fokus bahasan mendeskripsikan secara historis tentang gerak perjalanan Pesantren Cipasung mulai dari masa penjajahan Belanda, pendudukan Jepang, zaman kemerdekaan, dan kiprah pesantren di Nahdlatul Ulama (NU). Penulisan sejarah Pesantren Cipasung Singaparna dilakukan dengan menggunakan metode sejarah, yaitu: heuristik, kritik, intepretasi, dan historiografi. Pondok pesantren sekarang ini tidak hanya mengajarkan ilmu keagamaan, tetapi ilmu pengetahuan dan masalah keduniawian. Oleh karena itu, pondok Pesantren Cipasung Singaparna mempunyai tiga peranan penting, yaitu: sebagai lembaga pendidikan Islam, pengembangan sumber daya manusia, dan pengembangan masyarakat.
\end{abstract}

Kata kunci: pondok pesantren, Cipasung, perjuangan kemerdekaan.

\begin{abstract}
Muslim boarding school (pesantren) is an educational institution and study of Islamic which develop in the middle of the society in the traditional ways. Along with the developing of the era, traditional Muslim boarding school also become modern but still keep the religion values. This era can be seen in the $20^{\text {th }}$ century, the appearance of modern Muslim boarding school or the changes of traditional Muslim's boarding school into modern one. Thus boarding school got the displacement of orientation because they are not only teaching about ukhrowi (religiousness/the hereafter) but also about worldliness. It is because they need to adjust the period that they live right now. One of the Muslim's Boarding schools that has changed is Pesantren Cipasung Singaparna, Tasikmalaya Regency. The objective of this research is to reveal the history of Pesantren Cipasung Singaparna since the Dutch and Japanese colonialism, the era of Indonesian independence, until in the pace of NadhlatulUlama (NU) as the biggest Muslims organization in
\end{abstract}


Indonesia. The method that the writer used is historical method, which contains; heuristic, criticism, interpretation, and historiography. Muslim boarding schools in this era are not only taught about religiousness or the hereafter but also teach about worldliness or scientific knowledge. That is why Pesantren Cipasung Singaparna have three important roles; the institution of Islamic Study, the developing of human resources, and the developing of the society.

Keywords: Muslims Boarding school, Cipasung, struggle for Independence.

\section{A. PENDAHULUAN}

Ada beberapa pendapat tentang pengertian pondok pesantren. Salah satunya, menurut H. Amin Haedari dalam bukunya yang berjudul Transformasi Pesantren (2007), pondok pesantren adalah lembaga pendidikan Islam tertua yang merupakan produk budaya Indonesia. Keberadaan pesantren di Indonesia dimulai sejak Islam masuk negeri ini dengan mengadopsi sistem pendidikan keagamaan yang sebenarnya telah lama berkembang sebelum kedatangan Islam. Sebagai lembaga pendidikan yang telah lama berurat akar di negeri ini, pondok pesantren diakui memiliki andil yang sangat besar terhadap perjalanan sejarah bangsa (Haedari, 2007: 3 dalam http://ariffakhru.blogspot.com/2012/05/pen gertian-pondok-pesantren.html diakses tanggal 19 Mei 2014 pukul 12.30 WIB).

Dalam Kamus Besar Bahasa Indonesia, pesantren diartikan sebagai asrama, tempat santri, atau tempat muridmurid belajar mengaji. Sedangkan secara istilah pesantren adalah lembaga pendidikan Islam, di mana para santri biasanya tinggal di pondok (asrama) dengan materi pengajaran kitab-kitab klasik dan kitab-kitab umum, bertujuan untuk menguasai ilmu agama Islam secara detail, serta mengamalkannya sebagai pedoman hidup keseharian dengan menekankan pentingnya moral dalam kehidupan bermasyarakat. Namun Pondok pesantren secara definitif tidak dapat diberikan batasan yang tegas, melainkan terkandung fleksibilitas pengertian yang memenuhi ciri-ciri yang memberikan pengertian pondok pesantren. (http://ariffakhru.blogspot.com/2012/05/pe ngertian-pondok-pesantren.html diakses tanggal 19 Mei 2014 pukul 12.30 WIB).

Seiring perkembangan zaman, serta tuntutan masyarakat atas kebutuhan pendidikan umum, kini pesantren menyediakan pendidikan umum (kurikulum). Kemudian muncul istilah pesantren salafi (tradisional) dan pesantren modern. Pesantren salafi adalah pesantren yang murni mengajarkan pendidikan agama Islam yang kemudian disebut dengan istilah pesantren tradisional. Sedangkan pondok pesantren modern bukan hanya mengajarkan ilmu pendidikan agama Islam saja tetapi ilmu pengetahuan umum atau kurikulum. Materi di pondok pesantren modern campuran antara pendidikan ilmu formal dan ilmu agama Islam, para santri belajar seperti di sekolah umum atau madrasah. Pesantren campuran untuk tingkat SMP dikenal dengan nama Madrasah Tsanawiyah, sedangkan untuk tingkat SMA dengan nama Madrasah.

Salah satu pesantren tradisional yang telah berkembang menjadi pesantren modern adalah pesantren Cipasung Singaparna. Pesantren yang telah berdiri sejak zaman penjajahan Belanda memiliki peranan penting dalam meningkatkan pendidikan masyarakat, terutama masyarakat Tasikmalaya dan sekitarnya. Pesantren Cipasung, selain tetap menyelenggarakan sistem pendidikan pesantren tradisional juga memiliki lembaga pendidikan formal (sekolah), baik berupa sekolah umum maupun madrasah, sejak tingkat pendidikan dasar sampai perguruan tinggi.

Penelitian mengenai sejarah dan perkembangan pendidikan pesantren di Indonesia sudah banyak dilakukan. Oleh karena itu, pada kesempatan ini penulis melakukan penelitian sejarah Pesantren 
Cipasung Singaparna Tasikmalaya. Dengan fokus bahasan mendeskripsikan secara historis tentang gerak perjalanan Pesantren Cipasung mulai dari masa penjajahan Belanda, pendudukan Jepang, zaman kemerdekaan, dan kiprah pesantren di Nahdlatul Ulama (NU). Artikel ini diharapkan dapat menambah khasanah pengetahuan mengenai sejarah pesantren di Tasikmalaya maupun di Jawa Barat pada khususnya, dan Indonesia pada umumnya.

\section{B. METODE PENELITIAN}

Penulisan mengenai Sejarah Pesantren Cipasung Singaparna dalam pengumpulan sumber primer dan sekunder (heuristik) dilakukan melalui tiga tahapan. Pertama, penelitian lapangan (field-work) dengan sasaran objeknya di daerah Singaparna Kabupaten Tasikmalaya. Kedua, dengan melakukan wawancara kepada pimpinan pondok pesantren, K.H. Moh. Ilyas ketika beliau masih sehat walafiat dan kepada sesepuh atau tokoh masyarakat yang dianggap mengetahui tentang keberadaan pesantren Cipasung. Ketiga, mencari dan menghimpun data tulisan dilakukan dengan cara mendatangi perpustakaan-perpustakaan seperti perpustakaan Institut Agama Islam Cipasung (IAIC), Dinas Kebudayan dan Pariwisata Kabupaten Tasikmalaya, dan lain-lain.

Pada tahap kritik, untuk mendapatkan data yang valid dan otentik dilakukan pengujian terhadap data yang telah diperoleh. Selanjutnya, pada tahap interpretasi, data mengalami proses pemberian makna dan penafsiran sehingga fakta-fakta tersebut dapat menjelaskan objek studi secara jelas dan lengkap. Proses terakhir adalah historiografi yang bertujuan untuk merangkaikan fakta-fakta yang berhasil dihimpun dalam sebuah jalinan kisah sejarah yang objektif.

\section{HASIL DAN BAHASAN}

Pada awalnya, lembaga pesantren tidak dapat dikatakan sebagai lembaga pendidikan sekolah atau madrasah seperti yang ada sekarang. Berdirinya sebuah pesantren tidak dapat dipisahkan dari keadaan sosial budaya masyarakat sekitarnya. Tidak jarang tempat asal mula pesantren berada di pedukuhan kecil atau kampung yang penduduknya belum beragama atau belum menjalankan syariat agama Islam. Sekalipun tidak ada catatan tertulis mengenai keberadaan awal berdirinya sebuah pesantren, namun informasi lisan sering menceritakan mengenai keadaan lingkungan tempat yang akan menjadi lokasi pesantren. Pada masa dahulu, umumnya pesantren didirikan di daerah pedesaan, yang jauh dari keramaian masyarakat, misalnya di tengah sawah atau bukit.

Berdirinya pesantren di Indonesia sering memiliki latar belakang yang sama, yaitu dimulai dengan usaha seorang atau beberapa orang secara pribadi atau kolektif, yang berkeinginan mengajarkan ilmu pengetahuan agama kepada masyarakat luas. Mereka membuka kesempatan pengajian secara sederhana kepada penduduk setempat. Biasanya pengajian yang mula-mula dilaksanakan adalah berlatih membaca Al-Qur'an di mushola dan atau masjid yang sederhana. Beberapa waktu kemudian tumbuh kesadaran masyarakat setempat terhadap pengetahuan agama dan kelebihan yang dimiliki oleh mereka yang mengajar, sehingga banyak penduduk sekitar yang belajar agama. Akhirnya, masyarakat setempat memanggil pengajar dengan predikat kiai, dan khusus di Jawa Barat disebut Ajengan. Sedangkan mereka yang menuntut ilmu agama di tempat itu disebut santri (Dhofier, 1983: 51-60).

Perkembangan awal munculnya lembaga pesantren di Indonesia belum dapat dipastikan secara pasti karena kurangnya sumber tertulis. Berdasarkan data Departemen Agama tahun 1984/1985, jumlah pesantren di Indonesia pada abad ke-16 Masehi sebanyak 613 buah, tetapi tidak diketahui tahun berapa pesantrenpesantren itu didirikan (Ensiklopedia Islam 4, 1994: 101). Demikian pula, berdasarkan laporan Pemerintah Hindia Belanda 
diketahui bahwa pada tahun 1831 di Indonesia ada sejumlah 1.853 buah lembaga pendidikan Islam tradisional dengan jumlah murid sebanyak 16.556 orang. Hanya laporan itu belum memisahkan antara lembaga pengajian dengan lembaga pesantren, dan terbatas di pulau Jawa saja. Baru setelah ada laporan penelitian van den Berg pada tahun 1885, diketahui ada 14.929 buah lembaga pendidikan Islam di Indonesia, dengan 300 di antaranya merupakan lembaga pesantren. Jumlah murid pada saat itu sekitar 222.663 orang (Yacub, 1984: 6667). Lembaga pendidikan ini lebih banyak berada di pedesaan.

Pada akhir abad ke-19 Masehi perkembangan pendidikan pesantren sangat pesat. Indikatornya tampak dengan bertambah banyak orang Indonesia yang menunaikan ibadah haji ke Mekah, seperti Syekh Nawawi dari Banten, Syekh Mahfudz dari Pesantren Tremas yang kemudian menjadi staf pengajar tetap di masjidil Haram Mekah. Mereka diakui kebesarannya di Timur Tengah (Yacub, 1984: 67).

Perkembangan pesantren dari tahuh ke tahun makin pesat. Pada tahun 1920-an pesantren besar hanya mengasuh 200 orang. Pada tahun 1930-an jumlah santri pada pesantren besar melonjak hingga mencapai lebih dart 1500 orang (Yacub, 1984: 67). Hal ini membuktikan perkembangan agama Islam di Indonesia sangat pesat.

Di Kabupaten Tasikmalaya, pesantren telah berdiri sejak awal perkembangan agama Islam di daerah ini. Perkembangan pesantren awal itu kurang dapat diketahui karena tidak adanya dokumen tertulis. Pesantren yang sudah cukup maju (pesantren besar) pada zaman penjajahan Belanda cukup banyak, di antaranya Pesantren Cipasung, Cihideng, Sukamanah, dan Manonjaya. Pesantren Cipasung yang dipimpin oleh K.H. Ruhiat berkembang cukup pesat hingga sekarang telah menjadi pesantren modern, yang mengelola pendidikan formal dari tingkat pendidikan dasar sampai pendidikan tinggi (Perguruan Tinggi). Bahkan, Pesantren Cipasung telah menjadi pesantren modern yang besar dan penting di Jawa Barat, dan bahkan Indonesia.

Untuk menguraikan riwayat singkat berdirinya Pesantren Cipasung, terlebih dahulu akan diuraikan riwayat singkat K.H. Ruhiat yang ternyata sangat erat atau tidak dapat dipisahkan dengan riwayat pesantren tersebut. Oleh karena itu, menguraikan berdirinya Pesantren Cipasung berarti di dalamnya termasuk riwayat singkat kehidupan $\mathrm{K} \mathrm{H}$. Ruhiat.

\section{Awal Mula Berdirinya Pesantren Cipasung pada masa Penjajahan B elanda}

Pendirian Pesantren Cipasung berawal dari keinginan atau cita-cita dari seorang lurah atau kepala kampung di Desa Cipakat Kecamatan Singaparna Kabupaten Tasikmalaya yang bernama. $\mathrm{H}$. Abdul Ghopur bin Utsman. Dia bercita-cita ingin mempunyai anak yang menjadi ajengan atau guru agama di pesantren dan ambtenaar atau pegawai pemerintah (Wawancara dengan K.H. Dudung, Juni 2000). Oleh karena itu, H. Abdul Ghapur menyekolahkan anak-anaknya ke sekolah umum dan pesantren. Salah seorang anaknya yang mempunyai bakat dan minat terhadap ilmu agama adalah K.H. Ruhiat.

K.H. Ruhiat menamatkan pendidikan formal di sekolah Vervolg Sukasenang selama empat tahun. Pendidikan K.H. Ruhiat dilanjutkan ke berbagai pesantren, antara lain Pesantren Cilenga, Pesantren Sukaraja Garut, pesantren Kubang Cigalontang, dan Pesantren Cintawana. Seringnya perpindahan pesantren tersebut, bukan berarti K.H. Ruhiat mempunyai sifat hejo tihang (senang berpindah-pindah tempat), tetapi karena setiap pesantren memiliki kekhususan tertentu yang membuatnya berbeda dengan pesantren lainya, biasanya karena kekhususan disiplin ilmu yang diajarkan oleh kiainya. Misalnya, ada kiai 
yang khusus mengajarkan disiplin ilmu hadits, fikih, ilmu-ilmu bahasa Arab, ilmu tafsir, ilmu tasawuf, dan lain-lain. Oleh karena itu, K.H. Ruhiat mengikuti pendidikan di beberapa pesantren lebih dimaksudkan sebagai upaya untuk lebih memperkaya ilmu pengetahuan agamanya (Wawancara dengan K.H. Dudung, Juni 2000).

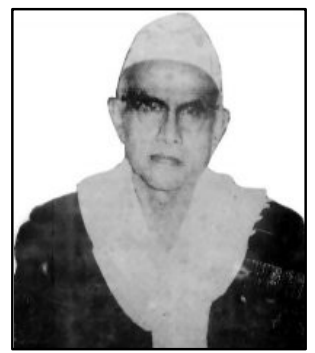

Gambar 1. K.H. Ruhiat

Sumber: http://profile.ak.fbcdn.net/, diakses tanggal 16 Juli 2014 pukul 13.30 WIB.

Bagi K.H. Ruhiat, Pesantren Cilenga merupakan pesantren pertama dan terakhir. Pada saat di Pesantren Cilenga, K.H. Ruhiat belajar bersama dengan K.H. Zainal Mustafa. Kedua sahabat itu telah mempunyai cita-cita untuk mendirikan pesantren. Cita-cita tersebut mendapat restu dan dukungan gurunya, K.H. Sumratulmuttaqien. Oleh karena itu, pada saat K.H. Ruhiat mendirikan Pesantren Cipasung, K.H. Sumratulmuttaqien menyertakan 40 orang santri kepada K.H. Ruhiat (Adeng, et al, 1999/2000: 34).

Setelah masantren (belajar di pesantren) selama 9 tahun (1922-1931), K.H. Ruhiat merasa sudah cukup ilmu untuk mendirikan pesantren. Ia mendirikan Pesantren Cipasung di Kampung Cipasung Desa Cipakat Singaparna Kabupaten Tasikmalaya pada tahun 1931. Penamaan pesantren disesuaikan dengan nama kampung tempat pesantren berada (Wawancara dengan K.H. Ilyas Ruhiat, Juni 2000).

Keberadaan Pesantren Cipasung bukanlah pesantren yang pertama di Kampung Cipasung. Sebelum Pesantren
Cipasung berdiri telah ada pesantren lain tetapi tidak dapat berkembang, bahkan akhirnya tidak ada kegiatan pengajian sama sekali. Melihat keadaan tersebut, K.H. Ruhiat berusaha merintis kembali kegiatan pengajian di lingkungan masyarakat Kampung Cipasung dengan mendirikan pesantren yang dinamakan Pesantren Cipasung.

Pesantren Cipasung didirikan berkat usaha mandiri dari K.H. Ruhiat. Bangunan pondok pesantren dibangun di atas tanah sawah milik ayahnya, $\mathrm{H}$. Abdul Ghapur. Tidak heran apabila di kemudian hari estafet pengelolaan Pesantren Cipasung tidak jatuh ke tangan orang lain, melainkan diturunkan kepada anakanaknya. Pewarisan kepemimpinan pesantren bersifat geneologis dan memang ini merupakan suatu yang lazim dalam dunia pesantren di Indonesia.

Bangunan awal komplek Pesantren Cipasung yang didirikan oleh K.H. Ruhiat adalah sebuah masjid, asrama atau pondok (tempat tinggal santri), dan rumah kiai. Semua bangunan itu berbentuk rumah panggung dan berbahan baku dari bambu (Wawancara dengan K.H. Ilyas Ruhiat, Juni 2000). Pondok yang pertama dan paling bersejarah adalah pondok yang sekarang dinamakan Pondok Pusaka.

Sebenarnya, banyak masyarakat sekitar yang bersedia menyerahkan tanah milik pribadinya sebagai wakaf untuk keperluan pesantren, seperti untuk mendirikan pondok (tempat menampung para santri mukim), mesjid, atau keperluan pesantren lainnya. Oleh karena pada waktu itu belum ada tata cara resmi mewakafkan tanah untuk kepentingan nama, secara praktis tanah wakaf itu diserahkan begitu saja kepada pengelola pesantren dan di kemudian hari menjadi wewenang kiai dan anak keturunannya. Pada umumnya, masyarakat menyerahkan tanah secara sukarela pada kiai sebagal tabungan awal untuk dirinya (Wawancara dengan K.H. Bunyamin Ruhiat, Juni 2000). 


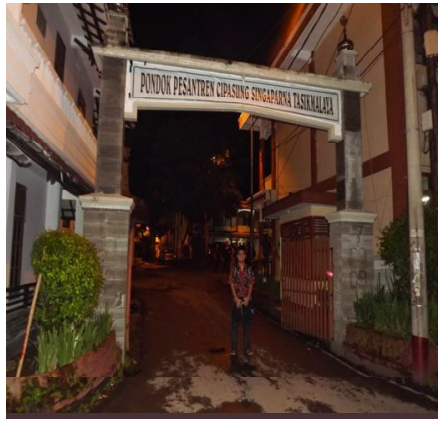

Gambar 2. Pondok Pesantren Cipasung Singaparna Tasikmalaya

Sumber : http://3.bp.blogspot.com/, diakses tanggal 16 Juli 2014 pukul 13.30 WIB.

Adanya bantuan dari masyarakat sekitar itu menunjukkan rasa memiliki masyarakat terhadap pesantren dan eratnya hubungan pesantren dengan masyarakat seakan-akan menjadi satu kesatuan. Oleh karena itu, tidak aneh apabila pendiri pesantren ini, K.H. Ruhiat memakai nama kampung tempat pesantren itu berada sebagai nama pesantrennya, yaitu Pesantren Cipasung. Keterikatan pesantren dengan masyarakat sekitar tampak pula dalam kehidupan keseharian terutama dalam bidang keamanan atau juga dalam pemberitahuan waktu shalat dengan menabuh bedug atau kentongan.

Upaya K.H. Ruhiat mendirikan Pesantren Cipasung mendapat dukungan dari pimpinan Pesantren Cilenga, tempat K.H. Rukhiat berguru. Pada awal berdirinya Pesantren Cipasung hanya memiliki 40 orang santri. Keempat puluh santri adalah modal awal K.H. Ruhiat yang berasal dari santri Pesantren Cilenga dan merupakan santri mukim. Selain santri mukim, terdapat pula santri kalong yang berasal dan masyarakat sekitar pesantren (Wawancara dengan K.H. Ilyas Ruhiat, Juni 2000).

Pada awalnya, kegiatan pengajian yang dilakukan K.H. Ruhiat kepada para santri di Pesantren Cipasung tidak dipungut biaya. Hal ini disebabkan kehidupan ekonomi kiai atau pemimpin pesantren relatif lebih dari cukup. Tanah yang dimiliki kiai berupa sawah dan kebun relatif cukup luas. Para santri diharuskan untuk bekerja di lahan tersebut dengan imbalan ilmu yang diberikan kepadanya. Ini dilakukan oleh santri yang berasal dari daerah yang jauh atau santri mukim. Sedangkan, santri kalong atau santri yang berasal dari daerah sekitar pesantren sering memberikan hadiah-hadiah, baik berupa hasil bumi maupun barang-barang yang dianggap pantas diberikan kepada kiai sebagai penghormatan.

Kegiatan pengajian yang dilakukan oleh K.H. Ruhiat sebagaimana kebanyakan pesantren tradisional saat itu, yaitu menggunakan metode sorogan dan bandungan. Materi yang diajarkan berkaitan dengan peningkatan keimanan dengan bersumber dari kitab-kitab kuning. Pengajian kitab kuning merupakan bentuk khas pesantren tradisional masih tetap dilakukan dan dipertahankan hingga sekarang. Penyampaian materi pengajian dilakukan oleh K.H. Ruhiat setelah melaksanakan shalat fardu. Jadwal pengajian tidak diorganisasi tetapi disesuaikan dengan waktu shalat fardu. Ini dimaksudkan agar mereka dapat melaksanakan shalat fardu secara berjamaah (Wawancara dengan K.H. Bunyamin Ruhiat, Juni 2000).

Sebagai pemimpin pesantren, K.H. Ruhiat termasuk ke dalam kelompok ulama yang independen. Artinya, ulama yang berada di luar birokrasi pemerintah dan berada dalam lingkungan masyarakat. Ulama independen umumnya adalah pemimpin dan pendiri pesantren yang berfungsi juga sebagai pelindung yang dihormati oleh rakyat. Mereka adalah panutan rakyat di lingkungannya.

K.H. Ruhiat giat melakukan dakwah di berbagai tempat di Tasikmalaya. Untuk memperluas pengaruh dan menjalin kerja sama dengan kiai lain, pada tahun 19.33 K.H. Ruhiat bersama dengan sahabatnya, K.H. Zainal Mustafa masuk dalam organisasi Islam yang bernama Nahdlatul Ulama (NU), yang berarti "Kebangkitan Ulama". Sebuah 
organisasi yang didirikan oleh Kiai Hasjim Asjari, pemimpin pesantren tradisional di Jombang Jawa Timur pada tahun 1926 (Ricklefs, 1991: 291). Padahal saat itu, di Tasikmalaya telah berdiri sebuah organisasi keagamaan (Islam) resmi, yaitu Izdharu Biatul Muluk Wal Amaro. Sebuah organisasi Islam yang didirikan tahun 1920-an oleh Bupati Tasikmalaya, R. Tanuningrat. Organisasi ini bersifat kooperatif terhadap pemerintah kolonial Belanda, sehingga pemimpinnya K.H. Sujani (sesepuh Pesantren Gudang di Kota Tasikmalaya) diberi anugerah Bintang oleh pemerintah. Sejak itu, K.H. Sujani dikenal sebagai 'Mama Bintang' artinya, orang tua dengan sebuah bintang (Kurasawa, 1993: 458-159).

Kiai dan ulama Tasikmalaya umumnya bergabung dalam organisasi tersebut. Setelah berdiri Nahdlatul Ularna Tasikmalaya, beberapa ulama keluar dari organisasi itu dan bergabung dengan Nandlatul Ulama. Ulama-ulama yang bergabung ke Nahdlatul Ulama adalah K.H. Ruhiat, K.H. Zainal Mustafa dan lain-lain. Dengan demikian, dimulailah keterpilahan antara ulama dari kedua kelompok tersebut (Adeng et al., 1999/2000: 28-29).

Pengaruh kelompok ulama Izdharu mulai melemah setelah kematian Bupati Tanuningrat. Persaingan antara dua kelompok ulama Izdharu dan Nandlatul Ulama) terus berlangsung hingga masa penjajahan Jepang. Kelompok Izdharu merupakan mayoritas dan kelompok NU merupakan minoritas. Ulama Izdharu yang terkemuka antara lain Kiai Fahrudin Mari Pesantren Nagasari. Sedangkan ulama yang terkemuka dari kelompok Nandlatul Ulama antara lain K.H. Zainal Mustafa dan K.H. Ruhiat (Adeng et al., 1999/2000: 2829).

Setelah K.H. Ruhiat menjadi pengurus Nandlatul Ulama, Pesantren Cipasung menjadi lebih terkenal dan banyak didatangi para santri dari berbagai daerah di Jawa Barat dan Jawa Tengah. Perubahan penting yang dilakukan oleh
K.H. Ruhiat dalam meningkatkan pendidikan pesantren adalah dimasukkannya sistem pendidikan madrasah dengan sistem klasikal (Wawancara dengan K.H. Ilyas Ruhiat, Juni 2000).

Inovasi pendidikan pesantren Cipasung tampak pada tahun 1935 dengan didirikannya Madrasah Diniyyah. Sekolah agama pertama di Pesantren Cipasung. Selanjutnya, pada tahun 1937 didirikan Kursus Kader Muballighin wal Musyawwirin (KKMM). Sebuah kursus untuk latihan pidato dan bermusyawarah bagi santri. Kursus ini dilaksanakan seminggu sekali setiap malam Kamis (Wawancara dengan K.H. Ilyas Ruhiat, Juni 2000).

Perkembangan Pesantren Cipasung dari tahun ke tahun terus meningkat. Santri-santri berdatangan dari berbagai daerah, tidak hanya dari sekitar Tasikmalaya. Dengan demikian, pengaruh K.H. Ruhiat semakin besar dan luas dalam masyarakat. Keadaan ini telah menimbulkan kecurigaan pihak pemerintah kolonial Belanda terhadap Pesantren Cipasung.

Pemerintah Belanda melalui matamatanya dan Polisi Intel (PI) terus mengamati perkembangan dan kegiatan Pesantren Cipasung. Pada saat yang sama, suasana peperangan di kawasan Asia Pasifik mulai berkobar yang ditandai dengan dihancurkannya Pangkalan Perang Amerika Serikat, Pearl Harbour Hawai oleh tentara Jepang (Marwati, 1992: 1-2). Akibat situasi peperangan Asia Pasifik yang mencemaskan telah menyebabkan pemerintah Belanda merasa ketakutan dan mencurigai kaum pergerakan nasional serta para pemimpin bangsa Indonesia. Gerakgerik mereka terus diawasi.

Pemerintah kolonial Belanda yang merasa khawatir akan terjadi pemberontakan rakyat, segera melakukan tindakan preventif dengan melakukan penangkapan-penangkapan. Rumah-rumah yang dicurigai digeledah. Para pemimpin yang berpengaruh dan ulama yang 
dicurigai menentang dan hendak menumbangkan pemerintah ditangkap dan dipenjarakan.

Pada hari Senin tanggal 17 Nopember 1941 atau bertepatan dengan tanggal 27 Syawal 1362 Hijriah, K.H. Ruhiat bersama K.H. Zainal Mustafa, H. Sjirod, dan Hambali Sjafei ditangkap oleh pemerintah kolonial Belanda. Mereka ditangkap dengan tuduhan menghasut rakyat untuk memberontak dan menumbangkan pemerintahan yang sah (Marlina, 1991: 21)

K.H. Ruhiat dan K.H. Zainal Mustafa dimasukkan ke penjara di Tasikmalaya. Keesokan harinya, tanggal 18 Nopember 1941, mereka diangkut ke Bandung dan dijebloskan ke penjara Sukamiskin. Penjara yang terkenal sebagai tempat pengasingan dan penyekapan tahanan politik. Bung Karno dan sejumlah pemimpin pergerakan nasional Indonesia lainnya pernah ditahan di penjara ini (Danoemihardja, 1970: 115). Pada saat K.H. Ruhiat berada di penjara, kegiatan pengajian di Pesantren Cipasung tetap dilaksanakan sebagaimana biasa. Kegiatan pengajian dilaksanakan oleh menantunya, K.H. Saefullah dan Ajengan Abdul Jabar.

K.H. Ruhiat dan K.H. Zainal Mustafa dibebaskan pada tanggal 10 Januari 1942. Tuduhan pemerintah Belanda tidak terbukti sama sekali. K.H. Ruhiat pulang kembali ke Pesantren Cipasung dan mengajar santri-santrinya seperti biasa. Pemerintah kolonial Belanda terus memonitor gerak-gerik K.H. Ruhiat. Pada akhirnya, bulan Februari 1942 K.H. Ruhiat dan K.H. Zainal Mustafa kembali ditangkap oleh pemerintah kolonial Belanda. Mereka ditahan dan dipenjarakan di penjara Ciamis (Sagimun, 1985: 58 dan Sjarief, 1970: 115).

Penangkapan K.H. Ruhiat dan K.H. Zainal Mustafa berdasarkan alasan yang sama dengan penangkapan pertama, yaitu menghasut pemuda (santri dan rakyat petani) untuk memberontak. Padahal baru sebulan sebelumnya, dia dibebaskan dari tuduhan serupa yang tidak terbukti.
Pemerintah Belanda dengan kekuasaannya bertindak sewenang-wenang terhadap orang yang hendak disingkirkannya. Jadi untuk kesekian kalinya, K.H. Ruhiat harus rneringkuk di dalam penjara. Banyak ulama di Jawa yang mengalami nasib yang sama pada akhir pemerintahan Kolonial Belanda (Kurasawa, 1993: 459).

\section{Keadaan Pesantren Cipasung pada Masa Penjajahan Jepang}

Pada awal tahun 1942, tentara Jepang berhasil mendarat di tiga tempat di Jawa., yaitu teluk Banten, Eretan Wetan Indramayu dan Rembang. Dalam waktu singkat, tentara Jepang berhasil melumpuhkan kekuatan Angkatan Perang Belanda. Akhirnya pada tanggal Maret 1942 Belanda menyerah tanpa syarat kepada bala tentara Jepang di Kalijati Subang, Jawa Barat (Poesponegoro, 1992: 4-5).

Untuk meraih simpati dan dukungan rakyat Indonesia, tentara Jepang segera membebaskan tahanan politik yang dipenjarakan oleh Belanda. Pada tanggal 31 Maret 1942, sebelas hari setelah menyerahnya pemerintah Kolonial Belanda kepada tentara Jepang, K.H. Ruhiat dibebaskan dari penjara Ciamis (Danoemihardja,, 1970: 114). Seorang kolonel tentara Jepang yang menjemput dan membebaskannya dari penjara Ciamis (Sagimun, 1985: 59). Tindakan ini dilakukan tentara Jepang sebagai salah satu upaya untuk membujuk dan mengajak K.H. Ruhiat agar mau bekerja sama dengan pemerintah pendudukan Jepang.

K.H. Ruhiat yang memiliki pengaruh cukup besar terhadap rakyat mendapat perhatian khusus dari tentara Jepang. Pihak Jepang berusaha menarik dukungan rakyat Singaparna dan sekitarnya dengan terlebih dahulu memanfaatkan keberadaan K.H. Ruhiat dan K.H. Zainal Mustafa dari Pesantren Sukamanah.

Dengan siasat yang nampaknya menghargai dan menghormati kaum ulama Islam, Pemerintah Pendudukan Jepang 
berusaha mendekati K.H. Ruhiat dan kiai Tasikmalaya lainnya. Pendekatan ini didasarkan pada keyakinan bahwa umumnya para ulama Islam lebih anti Barat daripada pemimpin pergerakan nasional sekuler. Golongan Islam yang berbasis pendidikan pesantren dalam sikapnya lebih anti Barat, daripada golongan pergerakan nasional yang berpendidikan formal (Barat). Kader anti Barat golongan pergerakan nasional relatif lebih rendah daripada golongan Islam (Ricklefs, 1992: 303-305). Oleh karena itu, pemerintah pendudukan Jepang secara hati hati dan berbau bujukan dalam berbagai kebijakannya, lebih banyak memberi kebebasan bergerak kepada golongan Islam daripada golongan nasionalis. Dengan demikian, golongan Islam mempunyai kebebasan bergerak yang lebih luas. Bahkan, golongan Islam diberi kesempatan untuk membentuk laskar sendiri yang dilatih kemiliteran oleh tentara Jepang, yaitu Hisbullah.

Pada masa pendudukan Jepang, penderitaan rakyat petani Desa Cipakat Singaparna sangat parah. Tindakan pemerintah pendudukan Jepang dari hari ke hari semakin meresahkan rakyat. Tentara Jepang dengan seenaknya mengambil padi rakyat. Rakyat yang menolak akan mendapat hukuman berat. Tidak jarang rakyat yang mati karena mempertahankan padi miliknya.

Rakyat petani semakin menderita dengan adanya kewajiban kerja paksa romusha. Tidak sedikit rakyat Desa Cipakat dan sekitarnya yang dipaksa menjadi romusha atau menurut istilah setempat di-romusha. Mereka dipekerjakan dengan sangat kejam, terutama pemuda dan laki-laki yang berusia antara 16 sampai 40 tahun dan para wanita atau gadis-gadis desa yang berusia antara 16 sampai 25 tahun dijerumuskan menjadi budak nafsu tentara Jepang di medan perang (Lebra, 1988: 158). Tidak sedikit gadis dari daerah Singaparna yang menjadi korban.

Selain itu, adanya peraturan pemerintah pendudukan Jepang mengenai beras dan tenaga kerja paksa romusha telah manyebabkan bahan pangan menghilang dari pedesaan den tenaga pertanian pun lenyap. Para pemuda desa yang merupakan tenaga kerja potensial di bidang pertanian telah terkuras karena tersedot oleh kerja paksa. Oleh karena itu, perekonomian masyarakat pedesaan menjadi terpuruk ke dalam kondisi yang lebih buruk daripada masyarakat di perkotaan. Daerah pedesaan yang merupakan produsen pangan justru menderita kelaparan. Oleh karena itu, di beberapa daerah pedesaan di Jawa terjadi bahaya kelaparan. Busung lapar melanda masyarakat pedesaan (Kurasawa, 1993: 92).

Penderitaan dan kesengsaraan merupakan pemandangan umum masyarakat Desa Cipakat. Bahan pangan (beras) sangat susah didapat, kalaupun ada umumnya di pasar gelap harganya sangat mahal. Garam pun hilang dari pasaran. Sebagian besar rakyat telah memakai pakaian yang tidak layak untuk ukuran kesehatan. Kaum laki-laki memakai pakaian dari karung goni yang kasar, ikat pinggang dari anyaman bambu, dan kopiah dari bulu domba, bahkan sebagian dari mereka ada yang hanya bercelana goni dan bertelanjang dada. Kaum perempuan tidak lagi memakai kain. Mereka telah mengganti kain dengan Iembaran kain karet dan pakaian karung goni kasar (Wawancara dengan Abah Anda, Juni 2000).

Penderitaan makin bertambah, karena tentara Jepang dan antek-anteknya seperti Keibodan dan Seinendan sering bertindak sewenang-wenang dengan menggeledah rumah-rumah petani untuk mengambil padi mereka. Tidak jarang para petani disiksa bahkan dibunuh karena tidak mau menyerahkan padi miliknya.

Rakyat lebih banyak diberi tugas dan kewajiban untuk kepentingan pemerintah, tanpa menghiraukan kehidupan mereka. Pemerintah pendudukan Jepang menugaskan para pejabat di kecamatan dan desa untuk melaksanakan program peningkatan 
produksi pangan untuk menopang biaya perang, seperti penanaman kacangkacangan, jarak, dan kaliki. Dalam program ini, sebagian masyarakat Singaparna dikenai kewajiban mengurus atau memelihara hileud (ulat sutra) dan menanam pohon kaliki. Malam hari yang harusnya digunakan untuk istirahat diberlakukan jam malam sehingga penduduk selalu diselimuti perasaan ketakutan. Dalam rumah tidak boleh ada cahaya lampu. Dinding-dinding rumah yang umumnya terbuat dari bilik (bilahan bambu) harus dicat hitam dengan ter. Hal ini dilakukan atas perintah pemerintah pendudukan Jepang agar pada malam hari terhindar dari serangan kapal terbang Sekutu (Adeng et al., 1999/2000: 27-28).

Adanya penderitaan dan kesengsaraan rakyat di sekitar Singaparna, terutama masyarakat Desa Cipakat telah diketahui oleh K.H. Ruhiat. Biasanya, rakyat yang terhimpit dalam penderitaan berusaha untuk mencari perlindungan dan keteduhan batin dengan cara religi, seperti konsultasi dengan orang yang dianggap memiliki kekuatan batin atau pada hal-hal yang bersifat mistis. K.H. Ruhiat sebagai ulama pemimpin pesantren sering mendapat laporan, baik langsung dari rakyat maupun dari para santrinya bahkan melihat sendiri. Beliau sangat sedih, tetapi tidak dapat berbuat hanyak untuk meringankan penderitaan rakyat karena tidak mempunyai kemampuan dan kekuatan untuk melawannya.

Kehidupan para penghuni

Pesantren Cipasung pun tidak lebih baik dari keadaan rakyat sekitarnya. Bahkan, Pesantren Cipasung lebih parah karena tekanan tentara Jepang. K.H. Ruhiat yang telah dibebaskan oleh tentara Jepang dari penjara Ciamis ternyata tidak mau bekerja sama. Padahal, pelepasan K.H. Ruhiat dimaksudkan agar dia mau dan bersedia bekerja sama dengan mereka.

Pada paruh pertama masa pendudukan Jepang, kehidupan santri Pesantren Cipasung sangat memprihatinkan. Pesantren kekurangan bahan pangan. Para santri yang umumnya berasal dari keluarga petani sebagian besar tidak mendapat suplai makanan (beras) dari orang tuanya. Hal ini disebabkan oleh berbagai faktor, antara lain panen padi gagal karena kemarau panjang, perampasan padi oleh penguasa jepang, dan larangan membawa beras (dalam jumlah tertentu) antara satu daerah ke daerah yang lain. Dengan demikian, hasil panen padi yang sedikit harus diserahkan pada pemerintah Jepang, sehingga untuk kebutuhan mereka sehari-hari tidak ada. Oleh karena itu, para santri harus bekerja ekstra untuk memenuhi kebutuhan hidup sehari-hari. Sebagian dari mereka, terutama santri pendatang yang berasal dari luar Singaparna terpaksa harus meninggalkan Pesantren Cipasung dan kembali ke daerah asalnya. Jumlah santri merosot tajam hingga hampir berkurang setengahnya (Kurawasa, 1993: 459-460).

Keadaan Pesantren Cipasung tersebut merupakan gejala umum yang melanda hampir semua pesantren dan masyarakat petani di sekitarnya. Rakyat petani mengalami penderitaan yang sangat parah karena mereka dibebani oleh kewajiban-kewajiban yang berat, seperti kerja paksa romusha dan penyerahan hasil bumi. Adanya kewajiban tersebut telah menguras potensi yang ada pada masyarakat petani pedesaan. Tenaga kerja paksa romusha dari daerah Tasikmalaya hanyak dipekerjakan di daerah penggalian timah hitam yang terdapat di Banten, Gunung Sawal dan Rawa Lakbok Ciamis, serta pegunungan di Jawa Barat untuk membuat kubu-kubu pertahanan (Ekadjati, et al., 1981/82: 171).

Meskipun demikian, keadaan Pesantren Cipasung pada sistem pembelajaran mengalami beberapa kemajuan yang lebih berarti dibandingkan pada masa penjajahan Belanda. Kemajuan tersebut ditandai dengan mulai adanya para santri putri yang dapat mengikuti pengajian "kitab besar" bersama santri putra. Pada masa sebelumnya, para santri putri hanya mengikuti pengajian sampai 
pada pengajian kitab-kitab menengah, seperti A1-Fiyah dan Fathul Mu'in.

Pelopor pengajian kitab besar oleh santri putri adalah $\mathrm{Hj}$. Sua. Seorang ustadzah dari Kampung Cilampung Leuwisari Singaparna yang menjadi pengajar tetap di Pesantren Cipasung. Sejak saat itulah, pengajian santri putri mengalami kemajuan yang cukup berarti dan menjadi bekal bagi peningkatan kualitas dan kuantitas santri putri di masa depan.

Hj. Sua berusaha untuk meningkatkan kualitas pendidikan santri putri. Pendidikan santri putri diarahkan untuk mencetak kader-kader muballighah yang handal dan dapat tampil ke depan sebagaimana santri putra. Untuk mewujudkan maksud tersebut, maka pada tahun 1943, Hj. Sua menyelenggarakan kursus kader muballighah. Kursus ini sebagal wacana latihan berpidato atau berceramah bagi santri putri (Wawancara dengan K.H. Ilyas Ruhiat, Juni 2000).

Keadaan pesantren Cipasung pada masa Jepang mengalami ketegangan emosional dan perasaan khawatir dari segenap santri akan kelangsungan pesantren ini ketika terjadi peristiwa perlawanan santri Sukamanah terhadap tentara Jepang. Pemerintah Jepang telah mengetahui hubungan antara K.H. Ruhiat (pemimpin Pesantren Cipasung) dengan K.H. Zainal Mustafa (pemimpin Pesantren Sukamanah), baik secara pribadi maupun pengurus organisasi Nandlatul Ulama. Pemerintah Jepang beranggapan pasti sedikit banyak K.H. Ruhiat ikut terlibat dalam peristiwa tersebut. Oleh karena itu, setelah terjadinya pemberontakan santri Sukamanah pada tahun 1944, dengan berbagai alasan dan untuk mencegah agar tidak menjalarnya virus pemberontakan, K.H. Ruhiat serta kiai-kiai lainnya yang dianggap terlibat atau mempunyai hubungan dengan pemberontak ditangkap dan dipenjarakan. K.H. Ruhiat dipenjarakan di penjara Tasikmalaya selama 2 bulan (Wawancara dengan K.H. Ilyas Ruhiat, Juni 2000).

\section{Perkembangan Pesantren Cipasung setelah Proklamasi Kermerdekaan}

Kemerdekaan

Indonesia

diproklamasikan pada tanggal 17 Agustus 1945. Adanya proklamasi kemerdekaan ini telah mengubah segala aspek kehidupan bangsa Indonesia, tidak terkecuali kehidupan pesantren termasuk Pesantren Cipasung.

Keadaan Pesantren Cipasung pada awal kemerdekaan Indonesia tidak lebih baik dari pesantren-pesantren lain yang ada di daerah Tasikmalaya. Pesantren kurang terurus karena keadaan yang kurang memberi kesempatan untuk mengurus pesantren. Santri Pesantren Cipasung banyak yang keluar dari pesantren untuk mengurus dirinya masing-masing. Sebagian dari santri tersebut banyak yang ikut terlibat dalam perjuangan mempertahankan den menegakkan Negara Republik Indonesia dari segala rongrongan, baik dari luar (Sekutu dan Belanda) maupun dari dalam (pemberontakan antar orang Indonesia sendiri).

Pada saat Agresi Militer Belanda II tahun 1949 terjadi peristiwa menggemparkan yang menimpa Pesantren Cipasung. Pada saat itu, K.H. Ruhiat dan tiga santrinya sedang melakukan shalat Ashar, secara tiba-tiba diserang oleh tentara Belanda. Tentara Belanda tanpa bertanya, langsung mengarahkan senjata dan menembak ke arah K.H. Ruhiat dan para santrinya. K.H. Ruhiat selamat dari tembakan tentara Belanda tersebut, sedangkan ketiga santrinya menjadi korban. Dua orang santri, Abdul Rojak yang berasal dari daerah Tawangbanteng dan Hamun yang herasal dari daerah Rancapaku meninggal di tempat, sedangkan seorang santri yang bernama Aen menderita luka parah di kepala (Wawancara dengan K.H. Ilyas Ruhiat, Juni 2000).

Selain itu, beberapa orang santri yang berada di sekitar tempat kejadian juga menjadi korban. Dua orang santri yang 
sedang berada di depan asrama ditembak oleh tentara Belanda. Santri yang bernama Abdul Alim ditembak hinggal meninggal dunia, sedangkan santri yang bernama Zainal Muttaqien mengalami luka parah karena tertembak bagian punggungnya (Wawancara dengan K.H. Ilyas Ruhiat, Juni 2000).

Sementara itu, K.H. Ruhiat yang luput dari tembakan tentara Belanda, akhirnya berhasil ditangkap. K.H. Ruhiat dimasukkan ke penjara Tasikmalaya selama 9 bulan. K.H. Ruhiat dibebaskan dari penjara setelah terjadinya pengakuan kedaulatan Republik Indonesia oleh Belanda pada tanggal 27 Desember 1949. Pada saat K.H. Ruhiat berada di penjara, pengajian di Pesantren Cipasung dilaksanakan dan dipimpin oleh K.H Saefulmillah dan putranya sendiri, K.H. Ilyas Ruhiat. Dengan demikian, Pesantren Cipasung tetap berfungsi dan bergerak dalam melakukan pendidikan agama Islam kepada para santrinya.

Peristiwa demi peristiwa yang menimpa Pesantren Cipasung, terutama yang menimpa K.H. Ruhiat sebagai pemimpin pesantren tidak menyurutkan perjuangannya. K.H. Ruhiat sebagai seorang pemimpin yang sabar dan berjiwa besar tetap bertahan dan selalu tawakal terhadap Allah. Pesantren Cipasung yang didirikan tetap berdiri tegak.

Perkembangan Pesantren Cipasung terus maju ke arah yang lebih baik, terutama setelah didirikannya beberapa sekolah pendidikan Islam yang berada di bawah naungannya. Sekolah yang pertama didirikan setelah merdeka adalah sekolah tingkat pertama yang bernama Sekolah Pendidikan Islam (SPI) pada tahun 1948. Dalam sekolah ini, selain diajarkan tentang agama Islam, juga diajarkan ilmu pengetahuan umum. Pada tahun 1953, SPI diubah namanya menjadi Sekolah Menengah Pertama Islam (SMPI). Selain itu, pada akhir tahun 1953, didirikan Sekolah Rendah Islam (SRI) yang selanjutnya diubah menjadi Madrasah Wajib Belajar (MWB). Madrasah Wajib
Belajar (MWB) kemudian diubah menjadi Madrasah Ibtidaiyah (MI) (Wawancara dengan K.H. Ilyas Ruhiat, Juni 2000).

Untuk melengkapi sekolah yang telah ada, pada tahun 1959 didirikan Sekolah Menengah Atas Islam (SMAI). Bahkan untuk lebih mengembangkan pendidikan pesantren Cipasung pada tanggal 25 September 1965 diresmikan berdirinya Fakultas Tarbiyyah, Perguruan Tinggi Islam Cipasung yang kemudian bernama Institut Agama Islam Cipasung (IAIC). Pada tahun 1970 didirikan Fakultas Ushuluddin Cipasung, tetapi hanya berjalan selama 2 tahun. Pada tahun 1997 didirikan Sekolah Tinggi Teknologi Cipasung (STTC) dengan dua jurusan, yaitu Jurusan Teknik dan Manajemen Industri serta Jurusan Teknik Lingkungan. Pada tahun 1999 didirikan Sekolah Tinggi Ilmu Ekonomi (STIE) Cipasung dengan dua jurusan yaitu, Jurusan Manajemen dan Jurusan Akuntansi. Pada tahun itu pula didirikan Fakultas Syariah sebagai pelengkap Fakultas Tarbiyah dan diresmikannya Koperasi Pondok Pesantren (Kopontren) Cipasung sebagai wadah kegiatan ekonomi bagi warga Pondok Pesantren Cipasung dan sekitarnya (Wawancara dengan K.H. Dudung dan K.H. Bunyamin, Juni 2000).

Pada tahun 1969 didirikan Sekolah Persiapan LAIN (SPAIN). SPAIN diubah namanya menjadi Madrasah Aliyah Negri (MAN) Cipasung pada tahun 1978. Untuk melengkapi SLIP telah ada, pada tanggal 1 Januari 1992 didirikan Madrasah Tsanawiyah.

Dengan tersedianya jalur-jalur pendidikan di Pondok Pesantren Cipasung dari tingkat pendidikan dasar sampai tingkat perguruan tinggi, menyebabkan banyaknya santri yang ingin menimba ilmu pengetahuan. Para santri dari berbagai daerah datang ke Cipasung, baik dari kabupaten-kabupaten yang ada di Provinsi Jawa Barat dan bahkan dari seluruh penjuru tanah air, seperti dari Irian dan Ambon.

Selain mengadakan pendidikan formal dalam bentuk sekolah maupun 
pesantren tradisional, Pesantren Cipasung juga melakukan berbagai kegiatan lain, seperti

- Majelis Ta'lim Pengajian (ibu-ibu dan bapak-bapak)

- Majelis Ta'lim Sholawatan

- Pengajian para kiai se-Tasikmalaya

- Pengajian para alumni dan masyarakat

- Biro Pengembangan dan Pengabdian Masyarakat (BP2M) - Koperasi Pondok Pesantren (Wawancara dengan K.H. Ilyas, Juni 2000)

Biro Pengembangan dan Pengabdian Masyarakat (BP2M) yang dibentuk pada tahun 1982 merupakan wujud kepedulian sosial pesantren terhadap masyarakat. Biro ini merupakan forum komunikasi, konsultasi dan kerja sama dalam merealisasikan model pengembangan desa terpadu yang pengembangannya menitikberatkan pada pengembangan sumber daya manusia. BP2M berusaha keras merangsang tumbuhnya kesadaran kelompok sasaran agar mampu berswadaya dan hidup mandiri.

\section{Kiprah Pesantren Cipasung dalam Gerak Perjalanan Nahdlatul Ulama (NU)}

NU adalah sebuah organisasi keagamaan yang didirikan pada tahun 1926 oleh sesepuh pesantren tradisional di Jombang Jawa Timur yang bernama Kiai Hasjim Asjari (Ricklefts, 1991: 291). Organisasi NU berkembang dengan pesat sehingga dalam waktu yang relatif singkat telah mempunyai cabang hampir di seluruh Indonesia. Menurut K.H. Aceng putra K.H. O. Qolyubi dari Madewangi Tamansari, disebutkan bahwa NU masuk ke Tasikmalaya sekitar tahun 1928. Orang yang pertama kali memperkenalkan NU di Tasikmalaya adalah K.H.M. Fadlil yang berasal dari Cikotok Ciamis yang kemudian menetap di Nagarawangi (Malik, 1993: 25).

Kehadiran NU di Tasikmalaya mendapat sambutan dari kalangan pesantren sebab secara kultural antara NU dengan pesantren terdapat hubungan yang erat. Oleh karena itu, hanya dalam waktu dua tahun, di Tasikmalaya segera terbentuk organisasi NU. Berdirinya NU di Tasikmalaya berawal dengan adanya rapat di kediaman K.H.M. Fadlil. Rapat tersebut memutuskan pendirian NU Tasikmalaya, dan K.H.M. Fadlil diangkat sebagai Rais Syuriyah dan H. Dasuki sebagai ketua. Setelah berdirinya NU, para kiai di Tasikmalaya segera bergabung ke dalam NU, di antaranya K.H.O Qolyubi, K. Shabandi, K.H. Dahlan, K.H. Ruhiat, K.H Yahya, K.H. Samsudin, K.H. Zainal Mustafa, dan lain-lain (Bunyamin, 1995: 4).

K.H. Ruhiat sangat aktif di Jam'iyyah NU sejak tahun 1930. Pada saat itu, K.H. Ruhiat masih menjadi santri di Pesantren Cilenga. Dengan demikian, dapat dikatakan bahwa K.H. Ruhiat merupakan salah seorang perintis NU di Tatar Sunda. Dalam NU, K.H. Ruhiat pernah memegang berbagai jabatan, antara lain Ketua Syuriah NU Kabupaten Tasikmalaya, anggota Syuriah NU wilayah Jawa Barat, dan Dewan Pengurus Besar NU Pusat. Oleh karena itu, tidaklah mengherankan bila Pesantren Cipasung makin terkenal bukan hanya di Jawa Barat, tetapi gaungnya dapat menembus ke wilayah Jawa Timur. Hal ini terbukti dengan banyaknya tokoh terkemuka NU yang berkunjung ke Pesantren Cipasung, seperti K.H. Wahid Hasyim, putra Almarhum K.H. Hasyim Asyari (tokoh sentral pendiri Nahdlatul Ulama) dan K.H. Muhamad Dahlan (seorang ketua pengurus Nahdlatul Ulama pada masa revolusi) (Shabirin, 1990: 83).

Sepanjang sejarahnya, Pesantren Cipasung secara kental diwarnai corak NU, terutama sekali dalam menyerap tradisi kepasantrenan. Namun demikian, dalam perkembangan selanjutnya, Pesantren Cipasung juga menyumbangkan warna dan corak terhadap sejarah NU di Tatar Sunda. Kulturisasi antara NU dengan Pesantren Cipasung disebabkan NU di wilayah Tatar Sunda bukanlah barang baru. Hal ini 
karena sejak pertama berdirinya organisasi NU, seorang ulama asal Jawa Barat yang telah turut serta dalam merencanakan lahirnya organisasi tersebut, yaitu K.H. Abdul Halim dari Jatiwangi, Majalengka. Dengan demikian, sangat wajar apabila para ulama di Jawa Barat senantiasa memperjuangkan kemajuan NU. Hal ini terlihat dengan diselenggarakannya delapan kali muktamar NU di Jawa Barat. Pertama, Muktamar VI di Cirebon pada tahun 1930. Kedua, Muktamar VII di Bandung pada tahun 1932. Ketiga, Muktamar VIII di Jakarta pada tahun 1933. Keempat, Muktamar XII di Menes, Banten pada tahun 1938. Kelima, Muktamar XVIII di Jakarta pada tahun 1950. Keenam, Muktamar XXII di Jakarta pada tahun 1959. Ketujuh, Muktamar XXIV di Bandung pada tahun 1968. Kedelapan, Muktamar XXIX di Tasikmalaya pada 1994 (Shabirin, 1990: 83-84).

Berdasarkan jalinan historis tersebut, Pesantren Cipasung selalu seiring dan sejalan dengan NU. Sebagaimana K.H. Ruhiat, K.H. Ilyas Ruhiat sebagai penerus pesantren Cipasung senantiasa menempa diri dan berjuang demi kemaslahatan umat melalui NU. Kiprah pertama K.H. Ilyas Ruhiat dimulai dari Ikatan Pelajar Nahdlatul Ulama (IPNU) dengan menjadi ketua IPNU Cabang Tasikmalaya periode 1954-1956, wakil ketua IPNU wilayah Jawa Barat tahun 1956, Rais Aam Syuriah Nahdlatul Ulama (NU) Cabang Tasikmalaya, Rais Syuriah wilayah Jawa Barat tahun 1985. Karir K.H. Ilyas Ruhiat terus meningkat menjadi Musytasar (penasehat) perwakilan wilayah Nahdlatul Ulama (PW-NU) Jawa Barat (Attarmizi, et al., 1999: 35).

\section{PEN UTUP}

Pondok Pesantren Cipasung, didirikan pada akhir tahun 1931 (tanggal dan bulan tidak diketahui) oleh K.H. Ruhiat. Pesantren tersebut terletak di Kampung Cipasung Desa Cipakat Singaparna Tasikmalaya. Pesantren Cipasung dalam perkembangan sejarahnya telah berhasil mewujudkan diri sebagai pesantren yang memiliki pandangan jauh ke depan. Para pengelola pesantren, sejak K.H. Ruhiat, K.H. Ilyas Ruhiat hingga K.H. Abun Bunyamin penerus sekarang telah memiliki pandangan modern tentang pendidikan. Dalam pandangan pemimpin Pesantren Cipasung, pendidikan agama Islam semata tidaklah lengkap sehingga perlu dilengkapi dengan pendidikan keduniawian dari sekolah umum. Oleh karena itu, Pesantren Cipasung memasukkan pelajaran tentang pengetahuan keduniawian dengan mendirikan lembaga-lembaga pendidikan mulai dari madrasah hingga ke perguruan tinggi.

Adanya perubahan-perubahan dalam pesantren, sebagaimana dilakukan Pesantren Cipasung, telah menjadikan pesantren tidak lagi dipandang sebagai lembaga eksklusif. Pesantren telah mengalami perubahan yang sangat terbuka dan menggembirakan. Pada saat ini, sudah saatnya orang berpikir bahwa pendidikan formal saja tidak cukup dapat diandalkan untuk mendidik manusia secara utuh. Banyak kalangan memandang dan mengeluh bahwa akhlak dan perilaku pelajar (generasi muda) ini cenderung merosot dengan berbagai bentuk tindakan yang meresahkan masyarakat. Krisis moral dan akhlak telah menggerogoti generasi muda bangsa ini. Untuk mengatasi keadaan tersebut, salah satu alternatif terbaik adalah pesantren.

\section{DAFTAR SUMBER}

1. Buku

Adeng, et al. 1999/2000.

Perlawanan Santri Pesantren Sukamanah terhadap Facisme Jepang dan Dampaknya terhadap Masyarakat Sekitarnya. Jakarta: Proyek IDSN.

Attarmizi, M. Yajid Kalam, K.H. Moh. Ilyas Ruhiat, 1999.

Ajengan Santun dari Cipasung. Bandung: Remaja Rosdakarya. 
Bunyamin, A.E., 1995.

Lintasan Sejarah Nahdlatul Ulama di Tasikmalaya. Stensilan.

Danoemihardja, Syarif Hidayat. 1970.

Riwayat Perjuangan Kiai Haji Zainal Mustafa, t.t.

Dhofier, Zamakhayari. 1983.

Tradisi Pesantren: Studi tentang Pandangan Hidup Kiai. Jakarta: LP3ES.

E. Shabirin, Nadj. 1990.

"Pesantren Cipasung Berkembang Seiring Semangat Zaman", dalam Pesantren No. 1/Vol.VII/1990.

Ekadjati, Edi et al., 1981/1982. Sejarah Kebangkitan Nasional Daerah Jawa Barat. Jakarta: Proyek IDKD.

Ensiklopedia Islam. 1994.

Jakarta: Ichtiar Baru van Hoeve.

Haedari, H.Amin, 2007.

Transformasi Pesantren, Jakarta: Media Nusantara.

Kurasawa, Aiko. 1993.

Mobilisasi dan Kontrol: Studi tentang Perubahan sosial di Pedesaan Jawa 1942-1945. Jakarta: Gramedia Widisarana.

Lebra, Joyce C. 1988.

Tentara Gemblengan Jepang, Jakarta: Pustaka Sinar Harapan.

Marlina, Itjeu. 1991.

Peranan Santri Pesantren Sukamanah terhadap Jepang Februari 1944. Bandung: Fasa UNPAD.

Poesponegoro, Marwati Djoened. 1992. Sejarah Nasional Indonesia Jilid IV. Jakarta: Balai Pustaka.

Ricklefs, M.C. 1991.

Sejarah Indonesia Modern. Yogyakarta: Gajah Mada University Press.
Sagimun MD. 1985

Perlawanan Rakyat Indonesia terhadap Facisme Jepang. Jakarta: Inti Idayu Press.

Yacub, H.M. 1984.

Pondok Pesantren dan Pembangunan Masyarakat Desa. Bandung: Angkasa.

\section{Internet}

http://ariffakhru.blogspot.com/2012/05/pengert ian-pondok-pesantren.html diakses tanggal 19 Mei 2014 pukul 12.30 WIB.

http://3.bp.blogspot.com/-N-vPYreaPJE/

Uznix8NDUCI/AAAAAAAAAUk/mHT3f59K6M O/s1600/DSCF2028.JPG, diakses tanggal 16 Juli 2014 pukul 13.30 WIB.

http://profile.ak.fbcdn.net/hprofile-ak-snc4/ hs464.snc4/50277_52006314239_1144688_n.j

pg, diakses tanggal 16 Juli 2014 pukul 13.30

WIB.

\section{Wawancara}

1. Nama : K.H. Moh. Ilyas Ruhiat 79 Tahun

Umur : S1

Pendidikan : Pemimpin Pondok

Pekerjaan : Pesantren Cipasung

Tahun 2000

Alamat :

Pesantren Cipasung

2. Nama : K.H. Dudung Abdul Halim, M.A.

Umur : $\quad 60$ Tahun

Pendidikan : S 2

Pekerjaan : Ketua MUI Kabupaten Tasikmalaya Tahun 2000.

Alamat : Pesantren Cipasung

3. Nama : K.H. A. Bunyamin Ruhiat

Umur : 58 Tahun

Pendidikan : S1

Pekerjaan : Dosen/Kepsek SMU Islam Cipasung Tahun 
2000

Alamat : Pesantren Cipasung

4. Nama : Abah Anda

Umur : 72 Tahun

Pendidikan : -

Pekerjaan : Petani

Alamat Singaparna

Tasikmalaya 